Sara Cetl', MA

Faculty of Education, University of Maribor

Original scientific paper

UDC: 37.032 .5

Assoc. Prof. Dr. Jerneja Herzog ${ }^{2}$

Faculty of Education, University of Maribor

DOI: $10.5937 /$ IstrPed2102548C

\title{
FINE ARTS CREATIVE SKILLS OF ELEMENTARY SCHOOL STUDENTS - AN ANALYTICAL DEMONSTRATION OF THE ROLE OF STRATUM
}

\begin{abstract}
The following article presents the results of research whose purpose was the analysis of the level of artistic creativity and fine arts development among eighth-grade students of different elementary schools in the northeastern part of Slovenia. We have monitored the level of artistic creativity and analysed the differences in fine arts creative skills from the viewpoint of six factors of artistic creativity: originality, flexibility, fluency, redefinition, elaboration and sensibility for artistic problems. Consistent with these factors, our focus was on the differences in the stratum, as we have noticed a lack of research analysing creative abilities from the point of view of the students' environment. Thus, the research aimed to shed light upon the impact of quality art educational work on the development of fine arts creative skills and creativity, especially among students of higher age. In doing so, the fact about the environment students come from was disregarded.

The results of the research show discrepancies with previous research, as we found statistically significant differences in the factors of art elaboration, sensibility for artistic problems and fluency, with the suburban students being more successful. For this reason, there are further tendencies to carry out an indepth analysis of this indicator in the mentioned age group.
\end{abstract}

Key words: artistic creativity, factors of artistic creativity, fine arts, stratum.

\section{Introduction}

Fine arts class is an educational process where students are also co-creators of the learning process. One of the fundamental aspects of fine arts as a school subject is the development of creativity, which is the actual process of artistic creativity through which the students obtain their skills and techniques (Duh \& Herzog, 2020).

There is no unified definition of creativity in the literature, however, the authors do not dissent completely in its word definition, on the contrary, they complement each other or emphasize particular aspects (Trstenjak, 1981). Guilford partly equates creativity with divergent thinking, an important element of artistic expression. It is based on different approaches, finding several different solutions to given problems and emphasizing individuality that is different from others. Duh defines artistic creativity as 'a product of a creative process; it has multiple meanings and is multi-layered' (Duh, 2004: 22). Torrance (1979) perceives creativity as a combination of three factors: motivation, ability and skill. He explains the model with the

\footnotetext{
${ }^{1}$ sara.cetl@student.um.si

2 jerneja.herzog@um.si
} 
example of a musician who must have a particular skill for playing a musical instrument, but at the same time, he must be able to create new melodies and be motivated to work. If any of these factors are missing, there is no creativity (Jausovec, 1983). In addition to originality, psychologists once understood usefulness as a factor for measuring creativity. According to them, the thinking was beneficial when it gave useful results. Many great ideas are not beneficial at a given moment, as we have developed them over the centuries, thus their usefulness is not always directly apparent (Pecjak, 1987). For example, Pecjak (1987) cites Leonardo da Vinci, who drew aeroplanes, tanks, submarines and clocks five hundred years ago. If we had a strong enough source of energy, most of his ideas would have worked even back then. The same is true of art, which many find useless at first. The emotions, satisfaction and mood that the artworks evoke in viewers are already considered beneficial (Ibid.). Runco (2004) finds that creativity has apparent benefits for individuals and society as a whole; that is why it is no surprise that much research has focused on creativity, especially in the last twenty years.

In 1965, George Land and his team developed a special test for NASA to select the most innovative engineers and scientists for their space program. As the test proved successful, it was also used for five-year-old preschool children in 1968 (Keong, 2008). There were 1,600 tested students, $98 \%$ of whom were at the level of a genius. After five years, the test was repeated, and the proportion dropped to $30 \%$ and after another five years to $12 \%$. When the test was then applied to adults, only $2 \%$ reached the genius level of creativity - out of 280,000 people (Sadar Soba, 2014). They have found out that creativity is declining. Children are exceptionally creative before starting school, but when they do start school, their creative abilities decline (Keong, 2008). Pecjak and Strukelj (2013) find that creativity decreases among children who live in monotonous conditions without incentives. Creativity cannot be taught as an ordinary subject. However, we influence creativity with our work and behaviour and with a creative environment in the classroom (Pecjak, 1987). Teachers are, in fact, crucial figures in providing a relevant, creative and enjoyable experience with art education (Duh \& Budefeld, 2018; Sharp \& Le Metais, 2000). The fine arts class is a significant factor in the development of students' abilities and in shaping their personalities (Duh \& Korosec, 2009). Kopacin (2014) points out that the leading goal of education should be to discover and promote the creative abilities of all students. Pecjak and Strukelj (2013) find that creativity decreases among children who live in monotonous conditions without incentives. Creativity cannot be taught as an ordinary subject. However, we influence creativity by the way we work and behave and by the creative climate in the classroom (Pecjak, 1987). Teachers are, in fact, crucial figures in providing a relevant, creative and enjoyable experience with art education (Duh \& Budefeld, 2018; Sharp \& Le Metais, 2000). The fine arts class is a significant factor in the development of students' abilities and in shaping their personalities (Duh \& Korosec, 2009). Kopacin (2014) points out that the leading goal of education should be to discover and promote the creative abilities of all students.

\section{Creativity in elementary school}

In education, the importance of creativity is recognized as an essential skill of the 21st century (Kupers et al., 2019). Tegelj (2008) says that it is in a child's nature to create a multitude of ideas about what he learns, create ideas about how the world works and to wonder how to find himself in it, react emotionally, think, explore and create. Kemple and Nissenberger (2000) argue that the early years are highly important in developing a child's creative potential. In early childhood, creativity begins with a game through which children learn and discover the world around them. Children do this through artistic creation seen in their drawings (Duh, Herzog, \& Lazar, 2014). The children's creativity is a cognitive necessity, points out Muhovic 
(1990). It is a motoric, rhythmic and sensory expression, which is a necessary factor in the fine arts development of children. The development of creativity is encouraged up to the limit set by heredity, explain Glogovec and Zagar (1992). This genetic creativity in a child should be carefully developed and not limited by external coercion (Hozjan, 2014). Runco (2007) finds that perhaps children are even more creative than adults, given their spontaneous creation without any hesitation. In the early phase, children fill the format with art design elements without prejudices, spontaneously and uncontrollably, even though they do not have any knowledge (Duh \& Korosec, 2009). This spontaneous artistic expression can acquire a broader cognitive value if the process of fine arts creative work is carefully planned. Art educational work is designed in such a way that children create art based on memory, imagination and direct observation (Duh \& Zupancic, 2009). Zupancic (2001) emphasizes that an expedient artwork is only the one that allows and develops a child's creativity, that is why special attention should be paid to the stage of the emergence of creative ideas. Herzog (2008) adds that this is manifested as a result of creative thinking and the intertwining of other subjective artistic factors.

The factors of artistic creativity that we examined in the research can be divided into two groups, within which we form three pairs that complement each other (Duh, 2004). Redefinition, fluency and elaboration constitute the first group, and originality, flexibility and sensibility for artistic problems the second (Herzog, 2009). 'Redefinition, fluency and elaboration (quantitative factors) are factors that enable creativity, as this element dominates in these factors and it also includes components of an encouraging character. On the other hand, originality, flexibility and sensibility for artistic problems (qualitative factors) are factors that promote creativity, as this is their predominant component, and at the same time, it also includes components that enable creativity' (Duh, 2004: 29). Each factor of artistic creativity is complemented by a complementary factor, and together they form a pair, namely, the first factor enables creativity, the second encourages it (Herzog, 2009). Factors that facilitate creativity provide the necessary material for creative work, and factors that encourage creativity motivate children to create something new (Duh, 2004).

In the factor of artistic originality, we monitor individual sensitivity and the author's original solutions. These are unexpected, without outside influence, i.e. as individual and original (Spirit, 2004). Flexibility in art activity is manifested in the search for and discovery of new paths, work procedures, the use of means of expression, techniques and other approaches to the depiction of motifs (Zupancic, 2001). In an artwork, sensibility for artistic problems is expressed in the artistic interpretation of an art motif as sensitivity to coherence between art components (Herzog, 2008). With the artistic redefinition that enables creativity, we check the success of artistic transposition, which manifests itself as a conscious redefinition of an idea, material or visual impression in the artistic structure (Herzog, 2009). Artistic fluency is reflected in motor skills in the realization of an idea, according to Herzog (2008). The elaboration is visible in the preparation of the creative process, i.e. in artistic purpose and realization procedures (Duh, 2004). The mentioned factors of artistic creativity are highly important for educational work, as they encourage students to be creative (Duh \& Zupancic, 2003). By promoting any factor of artistic creativity, we also activate all other factors (Herzog, 2009). Herzog (2008) conducted a study that examined the relationship between the factors of artistic creativity and their interaction, expressed in the level of overall artistic creative abilities. She found that artistic creativity is immanent to all and is similarly dispersed among students as other abilities. Artistic creativity is strongly correlated with general creativity, which means that the school subject of fine arts is at least equivalent to other school subjects in primary education (ibid.). 


\section{Research problem definition and methodology}

The purpose of the research was to determine the level of artistic creativity among students from the northeastern part of Slovenia. Students of eighth grade from various primary schools in the Maribor area participated. Our objective was to examine the differences in individual factors according to the stratum. Thus, the environment from which the students come (urban and suburban primary schools).

The research was based on the following research hypotheses.

General research hypothesis:

H1: There will be no statistically significant differences in the overall achievements in the level of artistic creativity from the stratum point of view.

\section{Specific research hypotheses:}

$\mathrm{H}_{\mathrm{SPEC}}$ : There are no statistically significant differences in the artistic factor of flexibility from the stratum point of view.

$\mathrm{H}_{\mathrm{SPEC} 2}$ : There are no statistically significant differences in the artistic factor of fluency from the stratum point of view.

$\mathrm{H}_{\mathrm{SPEC}}$ : There are no statistically significant differences in the artistic factor of originality from the stratum point of view.

$\mathrm{H}_{\mathrm{SPEC} 4}$ : There are no statistically significant differences in the artistic factor of sensibility for artistic problems from the stratum point of view.

$\mathrm{H}_{\mathrm{SPEC}}$ : There are no statistically significant differences in the artistic factor of elaboration from the stratum point of view.

$\mathrm{H}_{\text {SPEC }}$ : There are no statistically significant differences in the artistic factor of redefinition from the stratum point of view.

A causal non-experimental method of educational research was used in this research. The research sample consisted of a non-random sample of students, namely two suburban and two urban elementary schools. The research sample consisted of 101 participants of the eighth grade; 74 from the city and 27 from the suburbs.

Table 1: Numbers ( $f$ ) and structural percentages ( $f \%$ ) of students according to stratum.

\begin{tabular}{|l|c|c|}
\hline Stratum & $\mathbf{F}$ & $\mathbf{f} \%$ \\
\hline City & 74 & $73.3 \%$ \\
\hline Suburbs & 27 & $26.7 \%$ \\
\hline TOTAL & 101 & $100 \%$ \\
\hline
\end{tabular}

The testing was conducted in September 2020. We used the LV2 test, which consists of four tasks on different topics that the tested students needed to solve, showing their abilities of artistic expression. The test is derived from the evaluation criteria for assessing students' artworks (age of 3 to 18 ) and variance of deviation from the standard of development (Duh, 2004).

In the first artistic task 'Ponovi svoje najljubse likovno delo' (Repeat your favourite work of art) the students had to draw with crayons an artwork they chose as the most successful one or were specifically proud of it. The artistic task checked the originality of the artistic idea, the artistic structure and the level of redefinition, where the students had to identify elements that could be changed. In the second artistic task 'Skladnost barv in oblik' (Coherence of colours and shapes) students were required to draw a picture with crayons, featuring the harmony of 
colours and shapes. Here, the elaboration and sensibility for artistic problems are assessed as factors of creative development. The student shows how to design and plan a picture, and carries out the required design and colour harmony. The third artistic task 'Drobceno bitje opazuje notranjost starega debla' (A tiny creature observes the inside of an old trunk) was designed to highlight flexibility and fluency among the factors of artistic creativity. That is a distinctly imaginative theme, where students imagine a tiny creature observing the inside of an old trunk, which they draw with a black felt-tip pen. The task enables the assessment of flexible thinking, flexibility in the realization of artistic expression and the richness of artistic ideas and technical solutions. The fourth artistic task 'Diseca svetloba visine je ocarana nad razpetim sumom radostne vode' (The fragrant light of heights is enchanted by the noise of joyful water) requires students to transfer verbal signs into art. Students transform the poetic metaphors into an artistic sign with crayons. In the level of fine arts development, we assess originality, i.e. the original idea and original artistic structure; sensibility for artistic problems, which evaluates how well they discover the artistic problem and sensitize it artistically. As the last factor of artistic creativity, we evaluate the flexibility, namely flexible thinking and flexible realization of expression.

The test provides a wide range of tasks where the students can show various elements of their abilities of artistic expression. For each task, students were given 20 minutes. The 'Test of four drawings' has already proved reliable, valid and objective in previous research (Duh, 2004; Herzog, 2008; Herzog, 2009) and showed favourable results, thus we used it to test fine arts creative skills in our research as well. In the end, the complete students' artworks were encoded and evaluated by a panel of judges based on set criteria. There is a six-level scale with a range of 0 to 5 points in the LV2 test developed to assess individual factors of artistic creativity. For each factor of creativity, the student could receive a maximum of 5 points. The maximum total number is 30 points. The age of the students was taken into account during the assessment, and all students were tested in appropriate test conditions.

The obtained data were processed using the SPSS software. To determine differences between the strata, we used the t-test, which gathered results showing the arithmetic mean $\left(\overline{x^{*}}\right)$, standard deviation $(\mathrm{s})$, the test of homogeneity of variances and the test of differences between the arithmetic means.

\section{Results and discussion}

A comparison of the differences of individual factors of artistic creativity from the stratum point of view is depicted in Table 2.

Table 2: Results of the t-test and Levene's F-test of homogeneity of variances according to stratum in each factor of artistic creativity.

\begin{tabular}{|c|c|c|c|c|c|c|c|c|}
\hline \multirow{2}{*}{ Factor } & \multirow{2}{*}{ Stratum } & \multirow{2}{*}{$\mathbf{n}$} & \multirow{2}{*}{$\bar{x}$} & \multirow{2}{*}{$\mathbf{s}$} & \multicolumn{2}{|c|}{ Levene's F-test } & \multicolumn{2}{|c|}{ t-test } \\
\hline & & & & & $\mathbf{F}$ & $\mathbf{P}$ & $\mathbf{F}$ & $\mathbf{P}$ \\
\hline \multirow{2}{*}{ Sensibility } & City & 74 & 2.8378 & 1.04146 & \multirow{2}{*}{2.097} & \multirow{2}{*}{0.151} & \multirow{2}{*}{-4.802} & \multirow{2}{*}{0.000} \\
\hline & Suburbs & 27 & 4.0370 & 1.28547 & & & & \\
\hline \multirow{2}{*}{ Elaboration } & City & 74 & 1.7128 & 0.82728 & \multirow{2}{*}{1.501} & \multirow{2}{*}{0.223} & \multirow{2}{*}{-4.049} & \multirow{2}{*}{0.000} \\
\hline & Suburbs & 27 & 2.5093 & 0.99634 & & & & \\
\hline Flexibility & City & 74 & 3.0507 & 1.34977 & 0.060 & 0.808 & -1.346 & 0.181 \\
\hline
\end{tabular}




\begin{tabular}{|c|c|c|c|c|c|c|c|c|}
\hline & Suburbs & 27 & 3.4537 & 1.28047 & & & & \\
\hline \multirow{2}{*}{ Fluency } & City & 74 & 1.6723 & 0.82234 & \multirow{2}{*}{0.160} & \multirow{2}{*}{0.690} & \multirow{2}{*}{-2.231} & \multirow{2}{*}{0.028} \\
\hline & Suburbs & 27 & 2.0833 & 0.81157 & & & & \\
\hline \multirow{2}{*}{ Originality } & City & 74 & 3.4020 & 1.52031 & \multirow{2}{*}{0.142} & \multirow{2}{*}{0.707} & \multirow{2}{*}{0.947} & \multirow{2}{*}{0.346} \\
\hline & Suburbs & 27 & 3.0833 & 1.4311 & & & & \\
\hline \multirow{2}{*}{ Redefinition } & City & 74 & 1.6824 & 0.86434 & \multirow{2}{*}{0.000} & \multirow{2}{*}{0.989} & \multirow{2}{*}{-0.014} & \multirow{2}{*}{$0.98 \mathrm{c}$} \\
\hline & Suburbs & 27 & 4.6852 & 0.86489 & & & & \\
\hline
\end{tabular}

The results in Table 2 indicate that the assumption of homogeneity of variance is justified in all factors. There is a statistically significant difference in three factors of artistic creativity, namely in the sensibility for artistic problems $(P=0.000)$, elaboration $(P=0.000)$ and fluency $(P=0.028)$. In all three, the arithmetic mean is in favour of suburban students, which means that they are more skilled in the sensibility for artistic problems, more capable in the creative process of creating artistic expression and organized artistic structure and fluency of ideas, associations and motor skills.

There were no statistically significant differences in other factors. In the factors of artistic flexibility $(\mathrm{P}=0.181)$ and redefinition $(\mathrm{P}=0.989)$ suburban students achieved better results. In this case, they used the ideas in a new, unusual manner and discovered new ways. In the factor of artistic originality, the results are fairly similar, but the students from the city had more original ideas.

We were interested in whether there are differences in each factor of artistic creativity according to the stratum. These results refute the hypotheses $\mathrm{H}_{\mathrm{SPEC} 2}, \mathrm{H}_{\mathrm{SPEC}_{4}}$ and $\mathrm{H}_{\mathrm{SPEC}}$, which predicts that there will be no statistically significant differences in the factors of artistic creativity according to stratum.

Tabele 3: Results of the t-test and Leven's F-test of homogeneity of variances in the overall level of artistic creativity according to stratum.

\begin{tabular}{|c|c|c|c|c|c|c|c|c|}
\hline \multirow{2}{*}{ Factor } & \multirow{2}{*}{ Stratum } & \multirow{2}{*}{$\mathbf{n}$} & \multirow{2}{*}{$\bar{x}$} & \multirow{2}{*}{$\mathbf{s}$} & \multicolumn{2}{|c|}{ Levene's F-test } & \multicolumn{2}{|c|}{ t-test } \\
\hline & & & & & $\mathbf{F}$ & $\mathbf{P}$ & $\mathbf{F}$ & $\mathbf{P}$ \\
\hline \multirow{2}{*}{$\begin{array}{l}\text { Overall level of } \\
\text { artistic creativity }\end{array}$} & City & 74 & 14.3581 & 4.80565 & \multirow{2}{*}{0.229} & \multirow{2}{*}{0.633} & \multirow{2}{*}{-2.293} & \multirow{2}{*}{0.024} \\
\hline & Suburbs & 27 & 16.8519 & 4.92065 & & & & \\
\hline
\end{tabular}

The assumption of homogeneity of variance is justified $(F=0.229 ; P=0.633)$. There is a statistically significant difference $(P=0.024)$ in the overall level of artistic creativity between the strata. Suburban students achieved better results in the test of artistic creativity. We were interested if there were differences in the overall level of artistic creativity according to the stratum, and with these results, we can refute the hypothesis $(\mathrm{H} 1)$, which predicts that there will be no statistically significant differences in the overall achievements in the level of artistic creativity according to stratum.

\section{Conclusion}

We can conclude that statistically significant differences were detected in three factors of artistic creativity: sensibility for artistic problems, elaboration and fluency. In all three, the arithmetic mean is in favour of suburban students, which means that they are more skilled in 
the sensibility for artistic problems, and more capable in the creative process and motor skills. Suburban students achieved better results in flexibility and redefinition. Similarly, the results are fairly comparable in originality. However, students from the city had more original ideas. In the overall level of artistic creativity, students from the suburbs achieved better results.

In comparison to previous results of research conducted in the field of artistic creativity, the results are different. Hrusovar (2010), for example, found a statistically significant difference only in the fluency factor. The research showed that students from the urban environment achieved higher values in fluency than students from the suburbs. On the other hand, there are no statistically significant differences among the fourth-grade students of urban and suburban schools in the monitored factors of artistic creativity in the research of Gerjevic (2015). From the arithmetic mean, it is possible to anticipate better results of suburban students, except in the factor of originality, where students from the city performed better. Kac Nemanic (2017) also did not detect statistically significant differences in stratum in general artistic creativity in the research.

In the majority, there are no differences according to stratum in the previous studies. However, since our research revealed that suburban students were more successful in three factors of artistic creativity (fluency, elaboration and sensibility for artistic problems), we assume that differences in artistic creativity can be attributed to a more relaxed environment in suburban schools. Due to modern developments, there could be more discrepancies between suburban and urban students. Suburban students are probably more often part of multigenerational families, and they create more with their grandparents, take advantage of the natural resources of the environment, unlike urban children, who are limited in this. Surely, there are also socio-economic differences, and we assume that suburban students are more resourceful in the given circumstances and make the most of the situation. However, we must say that our results and conclusions with the interpretation of the results are our assumptions, which are certainly worth exploring in more detail in the future, especially on the extended research sample.

We can conclude that creative abilities are present in all children and are not just the privilege of individuals or gifted students. All children are creative, some more, others a bit less. It is important that their creativity evolves and is maintained into the adulthood.

\section{References:}

Duh, M. (2004). Vrednotenje kot didakticni problem pri likovni vzgoji. Maribor: Pedagoska fakulteta Maribor.

Duh, M. \& Budefeld, A. (2018). Gender difference in the linear relationship among factors of drawing-related creativity in second-grade primary school students. Nova prisutnost: casopis za intelektualna i duhovna pitanja, 16(2), 351-367.

Duh, M. \& Herzog, J. (2020). Likovna apreciacija v vzgoji in izobrazevanju: primeri kvalitativnih raziskav. Maribor: Univerzitetna zalozba Univerze.

Duh, M. \& Korosec, R. (2009). Likovnooblikovni razvoj ucencev v osnovni soli. Revija za elementarno izobrazevanje, 2(2/3), 33-41.

Duh, M. \& Zupancic, T. (2003). Likovna vzgoja v prvi triadi devetletne osnovne sole. Ljubljana: Rokus.

Duh, M. \& Zupancic, T. (2009). Sodobna likovna umetnost v kurikulu vrtca. Ljubljana: Zavod Republike Slovenije za solstvo. 
Duh, M., Herzog, J., \& Lazar, M. (2014). Likovno-intelektualni razvoj ucencev v razlicnih programih osnovnosolskega izobrazevanja. Revija za elementarno izobrazevanje, 7(1), 33-46.

Gerjevic, M. (2015). Likovni razvoj ucencev 4. razreda osnovne sole: diplomsko delo. [M. Gerjevic].

Glogovec, V. \& Zagar, D. (1992). Ustvarjalnost. Projektno vzgojno delo. Ljubljana: Zavod Republike Slovenije za solstvo in sport.

Herzog, J. (2008). Porazdelitev likovnoustvarjalnih sposobnosti med osnovnosolci. Revija za elementarno izobrazevanje, 1(3/4), 87-94.

Herzog, J. (2009). Dejavniki likovne ustvarjalnosti in likovnopedagosko delo. Revija za elementarno izobrazevanje, 2(2/3), 19-31.

Herzog, J. (2017). Spremljava likovnega razvoja ucencev $v$ tretjem vzgojno-izobrazevalnem obdobju osnovne sole - analiza stanja z vidika spola. Revija za elementarno izobrazevanje, 10(4), 349-364.

Hozjan, D. (2014). Konceptualizacija pojma ustvarjalnosti v solskem prostoru. Didakta, 24(171), 2-4.

Hrusovar, N. (2010). Primerjava likovno-ustvarjalnih dosezkov na razredni stopnji osnovne sole: diplomsko delo. [N. Hrusovar].

Jausovec, N. (1983). Problemski pouk in razvijanje ustvarjalnosti. Maribor: Pedagoska akademija.

Kac Nemanic, M. (2017). Ucinki inovativnega didakticnega pristopa na razvoj likovne ustvarjalnosti pri graficnem oblikovanju $v$ srednji soli: doktorska disertacija. http://pefprints.pef.uni-lj.si/id/eprint/5013

Kemple, K. and Nissenberg, S. (2000). Nurturing creativity in early childhood education: families are part of it. Early Childhood Education Journal, 28 (1), 67-71.

Keong, Y. K. (2008). Vsi smo ustvarjalni: naj vasa ustvarjalnost zacveti! Varazdin: Katarina Zrinski d.o.o.

Kupers, E., Lehmann-Wermser, A., McPherson, G., \& van Geert, P. (2019). Children's Creativity: A Theoretical Framework and Systematic Review. Review of Educational Research, 89(10), 93-124.

Muhovic, J. (1990). Odnos med otroskim likovnim izrazanjem in likovno ustvarjalnostjo odraslih,. Anthropos: casopis za psihologijo in filozofijo ter za sodelovanje humanisticnih ved, 22(3/4), 9-20.

Pecjak, V. (1987). Misliti, delati, ziveti ustvarjalno. Ljubljana: Drzavna zalozba Slovenije.

Pecjak, V., \& Strukelj, M. (2013). Ustvarjam, torej sem. Celovec: Mohorjeva zalozba.

Runco, M. (2004). Creativity. Annual Review of Psychology, 55, 657-687.

Runco, M. (2007). Creativity: Theories and Themes: Research, Development, and Practice. Amsterdam: Elsevier Academic Press.

Sadar Soba, N. (2014). Ustvarjalni gib: ustvarjalnost v gibanju. Didakta, 24(171), 8-12.

Trstenjak, A. (1981). Psihologija ustvarjalnosti. Ljubljana: Slovenska matica.

Zupancic, T. (2001). Likovno-ustvarjalni razvoj otrok v predsolskem obdobju. Ljubljana: Debora.

\section{Biographical notes:}

Sara Cetl, MA. She is PhD students in Faculty of Education, University of Maribor. Her field of resaerch is fine art education, fine art creativity and gifted children. 
Jerneja Herzog, PhD, Associate professor for fine art didactic in Department of Fine Art, Faculty of Education, University of Maribor. Her field of research is fine art education in elementary school and high school, creativity in fine art, gifted children, fine art in special pedagogy. 